Article

\title{
The Textuality of the Modernist Rural Landscape: Belgrade Agricultural Combine (PKB) as a Driver of the Urban Development of Third Belgrade
}

\author{
Vladan Djokić, Aleksandra Milovanović *(D) and Jelena Ristić Trajković(D) \\ Faculty of Architecture, University of Belgrade, Bulevar kralja Aleksandra 73/II, 11000 Belgrade, Serbia; \\ vdjokic@arh.bg.ac.rs (V.D.); jelena.ristic@arh.bg.ac.rs (J.R.T.) \\ * Correspondence: alekmil@arh.bg.ac.rs
}

Received: 18 October 2020; Accepted: 13 November 2020; Published: 17 November 2020

\begin{abstract}
This paper considers the landscape as both a material and an ideological representation and starts from the assumption that spatial patterns arise as a result of the ideological imperative of the process that forms the landscape. The research takes on a historical-interpretative approach in the domain of architectural and urban studies, enabling in-depth qualitative exploration of the textuality and layering of the modernist rural landscape through a case study of the PKB Agricultural Combine as a driver of the urban development of Third Belgrade, the spatial framework of the left riverbank of the Danube in the administrative area of Belgrade. The research was conducted by chronologically interpreting primary sources, notably planning documents of different levels and scope, as well as studies, programs and development models for the urbanization of this territory. The research aims to decode the impact of socialist agrarian policy on the land-use in the wider metropolitan area of Belgrade, as well as the impact of the agricultural combine as a spatial, social, economic, environmental and political entity on the urban development process at different spatial levels. The research has identified four periods in the development of Third Belgrade: (1) Production of the Modernist Rural Landscape, (2) Establishment of the Self-Management Planning Framework, (3) Humanization of Environment, and (4) Post-socialist Transition and the Collapse of the Agricultural Combine. The paper demonstrates not only that environmental transformation cannot be separated from social transformation but also that they are in constant interaction and that their synergy has had a profound impact on the development of the PKB Agricultural Combine system in socialist conditions. The textuality of the modernist rural landscape confirms that an object-oriented approach is not enough to explore and interpret the landscape, but rather, we should look at the way it is socially produced through decoding the planning, institutional and policy frameworks determining the urban development of a territory.
\end{abstract}

Keywords: landscape typology; agricultural landscape; cultural landscape; land use intensification; architectural design and urban planning; environmental transformation; socialist self-management; modernism; humanization of environment

\section{Introduction}

The perception, interpretation and description of the landscape have long been based on its passive nature, relying primarily on the perspective established within the traditional geographical studies that interpret the landscape as a physical entity and an external world that can be empirically accessed and analyzed [1]. In line with the above approach, the landscape was analyzed by historical reconstruction, and its evolution through observation and the recording of material facts about a certain territory [2]. According to Widgren [3], traditional landscape studies commonly employ a morphogenesis-oriented 
perspective, that is, they identify the emergence of form, spatial patterns and physical structures without parallel consideration of the relevant social, cultural and environmental processes.

The debate on the landscape phenomenon in the framework of the 1967 International Union of Architects (UIA) Congress in Prague created a significant step in the more complex establishment of the definition of the landscape and its relation to the cityscape. In the first place, the landscape was defined as "one of the basic forms of the human milieu" [4] (p. 45) whose natural resources can be conserved by strengthening the planned economy, based on the thesis that correlating social needs, activities and appropriate characteristics of the landscape creates its functions. In terms of the functional aspects of the landscape, Toth [5] proposes a new, soft paradigm to study landscapes and territories focused on analyzing function and then the spatial dimension and structure, and singles out the following perspectives for landscape research: (a) determining the level of mutual adaptation between users and their surroundings, and (b) how to create sites, orientation and hierarchy in relation to site users.

In the European Convention on Landscapes, the landscape is defined as "an area, as viewed by the population, whose character is the result of actions and interactions of natural and/or cultural factors" [6]. This definition was heavily influenced by the changes that occurred at the end of the 20th century in the perception and observation of landscapes, which shifted from analyzing visual aspects to understanding the landscape as a representation. Leaving the aesthetic dimension aside, Duncan opens a perspective focused on viewing the landscape as text, as a social and cultural document whose reading creates an understanding of the layers and processes inscribed in it, or creates an ideological representation [7]. In the same sense, Daniels [8] recognizes the double-sidedness of the landscape, pointing out that the landscape is equally a material and an ideological representation. This duplicity is also reflected in the discursive positioning of landscape studies. Emphasizing that no environmental interpretation or policy can neglect the effect of creating cultural meaning, Cosgrove [9] distinguishes between two different discourses within landscape studies-the semiotic and the ecological. This differentiation also acknowledges the significant role of semiotic concepts and methodologies in exploring how meanings are created, represented, communicated and stored in and through landscapes, their structures and elements. Against this background, Duncan and Duncan [10] define the "landscape as text" to be read critically on the basis of structuralist semiotics so that it designates a system for the production and transmission of cultural meanings. The process-oriented and dynamic nature of the landscape is further highlighted by W.J.T. Mitchell [11] who defines landscape as a verb rather than a noun, object or image through which only the aesthetic dimension is read, as opposed to Harvey's view of the landscape as a constructed form, or as a geographically defined and complex product fixed in space [12].

According to Widgren [3], studies of the landscape at the present moment should include a threefold conceptual orientation: (a) landscape as appearance-an idea, a way of seeing and representation, (b) landscape as institution-a mode of communication and social order and (c) landscape as resource — capital, involving use and production. This further contributes to expanding the concept of the landscape towards its definition as an "experienced human habitat, in relation to the understanding of land as both a common resource, and as pieces of property" [13] (p. 1). Such theoretical settings indicate that landscape studies have transitioned from the passive symbolic representation to an affirmation of the dynamic nature of landscapes, thus opening the possibility of viewing landscapes as texts whose reading provides an understanding of the landscape as an ideological representation.

\subsection{Modernist Rural Landscape}

In the socialist era, many Central and Eastern European states, including the Balkan countries within the Yugoslav cultural space, experienced an intensive transformation of agricultural landscapes and landscape patterns, as well as the redistribution of their relations on the basis of collectivization and self-governing management. Rural landscapes were affected by a wide range of social, economic, demographic and technological trends relying primarily on the productivist agricultural regime [14]. 
The impact of the modern movement on the rural landscape, which began to unfold as early as in the mid-19th century through experiments in utopian socialism and radical state reforms, became more intense in the 1920s, especially in late colonization and within new political movements, such as fascism, socialism, communism, Zionism, anarchism and the cooperative movement [15]. States, governmental organizations, movements and collectives engaged in extensive actions to reshape rural landscapes in order to address the underutilization of arable land and the underdevelopment of the agriculture sector [16-18]. Moreover, the socialist system enabled the systematic implementation of the principles of Congress International d'Architecture Moderne (CIAM) on a large urban scale, in contrast to capitalist countries where this was done on smaller scales, which allowed significantly more intense urban transformation and greater changes in the physiognomy and typology of the landscape. For this reason, the concept of rurality is also reviewed in this paper and the relationship between rural and modern, as well as between rural and urban, is problematized.

Such modernist changes are evident in the first post-war period of morphogenesis and urban development of the City of Belgrade, primarily enabled by its new position translated from a border city into the center of a vast state. In the first years after WWII, the features of socialist modernization included a focus on (1) technological and economic development, based chiefly on the socialist construction of a new society, which initially required changes aimed at enhancing the economy, and (2) reaching a certain level of professional-qualification status of both the individual and the collective with the goal of establishing and institutionalizing a novel system of social relations as well as a general change in worldview and society. Through a series of administrative and territorial changes that have taken place since 1955, the city territory has been expanded to include nearby rural and urban settlements which, in economic terms, directly gravitate to the city and together with it represent a unique economic and urban area. In this way, the conditions were created to connect the cityscape of Belgrade with its closest natural hinterland, that is, the closest rural landscape, whose economic, communal, social and cultural development was directly linked to and conditioned by the development of the city. As Mandic [19] writes, the notion of the city stretches beyond the built-up area and goes deeper into the hinterland, which is why a city cannot be viewed "in isolation from the environment and the space in which it is located." Such decisions on territorial organization established the initial ground for the development of the entire agricultural territory in the metropolitan area of Belgrade. According to Bozovic [20], the disappearance of the city's border and its uncontrolled and destructive identification with the territory, both in the legal and physical sense, "hint at a creation that can be defined as an urban landscape." It can be said that this term on the social plane signifies "the totality of manifesting the dominance of the city over the country" [21] (p. 4), while in physical and spatial terms, it implies the absolute dominance of the cultural over the natural landscape.

Starting from the developmental level of production forces, Stefanovic [22] looks at urbanization through its four characteristic phases: primary-rural, secondary-industrial, tertiary and quaternary-regional. In this sense, the first phase was represented by a migration from the rural scene to the city, after which came the inverse process, which meant that urbanization did not stop at the borders of the urban area but also affected the rural landscape. Through such processes, the tendency was clearly reflected to gradually integrate previously isolated urban and rural spaces into unique regional agglomeration systems. In the post-war period, these issues were very topical for the Yugoslav conditions, and especially for Belgrade, which developed into the largest agglomeration in the country. Considering the impact of immigrants from rural areas on the urban environment and the intense annual growth of 25,000 new residents in Belgrade, Papic [23] highlights the transition from an individual, autarchic economy to large-scale social industrial production in accordance with the better living conditions associated with urbanization. The direct link between population movement and economic development indicates that the economy had evolved and stagnated in the face of demographic change. Each phase of population growth was accompanied by a corresponding development of economic activity that had a direct impact on the transformation of the rural landscape. These changes suggest that the urbanization was not a one-way process and did not always have a 
positive flow, given that the process of ruralization was underway at the same time. According to Halpern [24], this process can also be defined as modern ruralization, which implies a strong influence of rural habits on the urban area, bearing in mind that the mutual influences of the rural scene and the city concern not only economic but also social relations. Thus, the urbanization that extended to rural areas and non-urbanized land on the one hand, and the ruralization of all social strata on the other, were mutually pervading processes of migration through which the immigrant population left their mark of traditional culture, way of life, behaviors and aspirations.

The explained process of modern ruralization initiates thinking about a new, unique typology of landscapes-the modernist rural landscape. Significant progress in the study of these topics has been made within the project MODSCAPES (2016-2019), which explored rural landscapes produced by the large-scale agricultural development and colonization schemes planned in the 20th century through a wide range of evidence-based research from primary and secondary data sources, including policy analysis, archival material, field surveys, historical landscape mapping, etc. [25]. This transnational research project has investigated 11 case studies across Europe and beyond. However, the case study did not include the spatial framework of the Balkan countries and the former Yugoslav cultural space, which also holds valuable records and traces of the heritage of large-scale agricultural combines. In this sense, our research offers a supplement to the gap in the territorial coverage of this thematic study at the present time.

The modernist rural landscape and many of the related concepts (modern ruralization, modernist agricultural landscape, traditional agricultural landscape) are waiting for a global study capable of putting a value on its role in the urban planning sector, its potential for urban-rural revitalization and its benefits for heritage conservation. The value of these concepts in current studies is identified in accordance with the conceptual framework of cultural heritage and cultural landscape, specifically heritage landscape and shared heritage [26], which also contributes to the repositioning of the topic of traditional landscape in contemporary landscape studies. Discussion on the concept of traditional, mostly agricultural landscapes, their ambiguous nature and connections to contemporary landscape research and practice has been problematized and challenged within the Permanent European Conference for the Study of the Rural Landscape (PECSRL), organized by the Institute for Research on European Agricultural Landscapes. The discussion resulted in the identification of four central aspects crucial for future research activities, including (a) dynamic landscape histories, (b) a participatory approach to landscape management, (c) socioeconomically and ecologically self-sustaining landscapes, and (d) planners as intermediaries between development and preservation, and also questioned the future of traditional landscapes [27]. In contemporary times, this issue is becoming more complex due to the ongoing transformation of large agricultural systems and agricultural land abandonment. Little progress has been made in understanding the global patterns, drivers and implications of agricultural land abandonment. Therefore, today, when modernist agricultural landscapes are transitioning to landscape brownfields, it is important to understand their background from a scientific perspective and to provide the policy makers and planning practitioners all the data needed for the proper and efficient management of these landscapes. Setting up this kind of a value system would yield novel research goals aimed at decoding the textuality of agricultural combines as agro-industrial heritage sites.

\subsection{Objectives and Paper Outline}

The paper starts from the point of view of authors whose landscape research is based on the semiotic reading of the landscape as text $[7,10,28,29]$, that is, on the interpretation of textuality that acts as a marking system through which social, cultural, political and economic systems are communicated, experienced and explored. The landscape is considered as an equally material and ideological representation, following the assumption that spatial patterns arise as a result of the ideological imperative of the process that forms the landscape. The basic research question of the paper is concerned with discovering how different landscape dimensions affect it as a totality in the spatial 
and social sense. Hence, the tendency is to consider the landscape as an ideological play in place of an external and material reality. This research, through which the described theoretical position is introduced as a methodological apparatus for reading the landscape, focuses on the relationship between landscape structure and the ideology of economic development of Socialist Yugoslavia within the spatial framework of the left riverbank of the Danube in the administrative area of Belgrade. The subject of the research is the system of the Belgrade Agricultural Combine, known as PKB, which, since its founding in 1945, has become a major "producer, urban planner and realizer" on the territory of the Danube's left riverbank in Belgrade. The intention is to look at how the urban planning, urban and architectural design and architectural programming of an agricultural combine, as an economic, political, industrial and housing system, affected the representation and construction of a new socialist life of the working people and the production of modernist rural landscapes by focusing on a few central research questions:

- What are the impacts of socialist agrarian policy on the use of land in the wider metropolitan area of Belgrade?

- What is the impact of the agricultural combine as a spatial, social, economic, environmental and political entity on the urban development process?

- What is the relationship between the ideology of the socialist self-management society and spatial planning in the context of the Belgrade Agricultural Combine (PKB)?

- How is the production of modernist rural landscapes manifested at different spatial levels?

The paper consists of three parts. The first part describes the Materials and Methods. The second part of the paper is a discussion on the research findings of the case study-Belgrade Agricultural Combine (PKB) -identifying four key phases in the development of this territory: (1) Production of the Modernist Rural Landscape, (2) Establishment of the Self-management Planning Framework, (3) Humanization of Environment and (4) Post-socialist Transition and the Collapse of the Agricultural Combine. The final portion of the paper contains concluding remarks on the initially established research questions.

\section{Materials and Methods}

\subsection{Study Case Area}

Belgrade's geographical location at the confluence of two European rivers-the Danube and the Sava - was one of the fundamental preconditions for the morphogenesis of the city's territory and its expansion towards the wider metropolitan area. Overall, the morphogenesis of Belgrade and its modern urbanization took place in strokes-which can be recognized within its spatial-morphological systems of Old Belgrade (historical city), New Belgrade (modernist city), positioned on the right riverbank of the Danube, and Third Belgrade (agrarian city) located on the Danube's left riverbank [30,31]. Third Belgrade is bounded on the south and west by the Danube River and on the east and north sides by the tributary of the Danube, the Tamis River. This territory is characterized by a specific landscape configuration and an urban morphology in line with the development of the PKB Agricultural Combine, and it was predominantly intended for agriculture. The research covers an area of 37,000 ha-2110 ha of built environment and 34,890 ha of PKB's agricultural area.

Current trends in globalization, the economic crisis, suppression of agriculture in the city's metropolitan area, as well as the transition from a state-controlled economy to an open-market economy have all led to the collapse of this agricultural combine system, which today is a vast brownfield territory for a re-selective use of the past in accordance with contemporary urban development strategies and innovative planning principles. At this time, many European cities [32-35] are facing numbers of abandoned facilities that used to be part of the agricultural industry and combines, making this research an example for future researchers and practitioners on how to read and comprehend the textuality of modernist rural landscapes. In 2018, the entire area of the PKB Agricultural Combine (comprising 40\% 
of the administrative territory of the City of Belgrade, with a system of seven small settlements of exceptional locally specific cultural and natural features and architectural heritage, as well as a series of abandoned industrial buildings positioned in an area of exceptional ecological values) was privatized and has now become a brownfield territory requiring new processes of transformation and urban transition (Figure 1). In this sense, Third Belgrade represents a critical framework for the analysis of research questions posed in the context of the former Yugoslav cultural space.

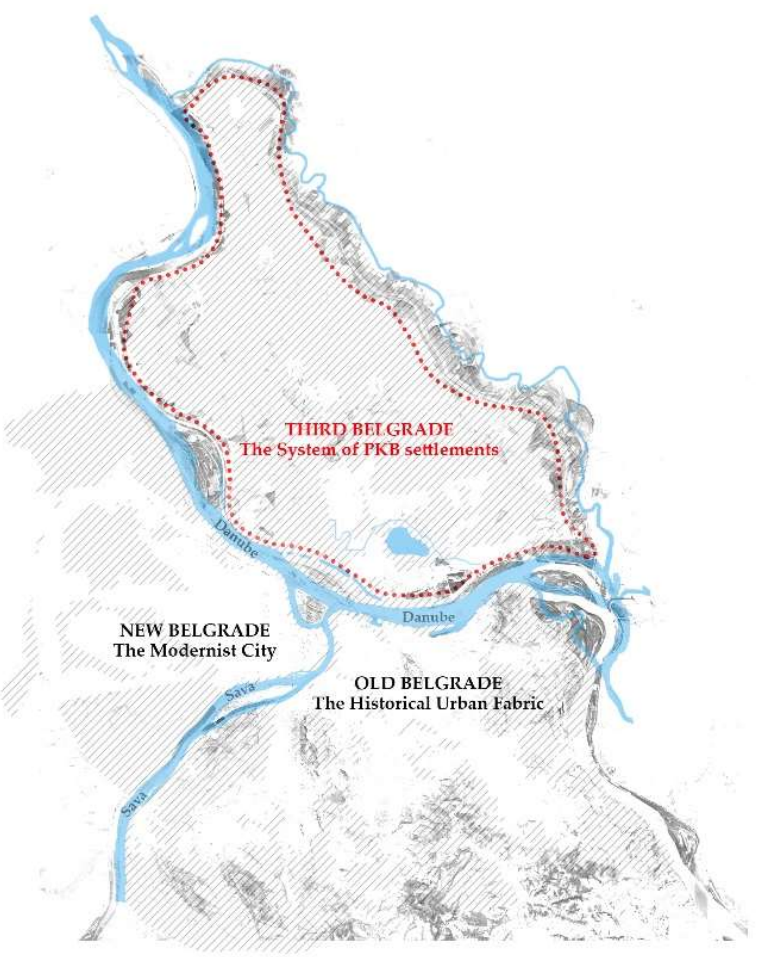

Figure 1. The Case Study spatial framework: Third Belgrade spatial coverage (red lineout). Source: Authors.

Previous research on the urbanization of Belgrade and landscape transformation in the socialist context has dominantly focused on the territory of New Belgrade [36-39], while the spatial coverage of the left bank of the Danube and the PKB Agricultural Combine system, which emerged in parallel with New Belgrade, has never been the subject of urban and architectural studies. Accordingly, this research provides a significant addition to the understanding of landscape transformation and changes in land use intensity within Belgrade's administrative territory.

\subsection{Data and Methodology}

The research takes on a historical-interpretative approach in the domain of architectural and urban studies, enabling in-depth qualitative exploration of the textuality and layering of the modernist rural landscape. The research was conducted by chronologically interpreting primary sources, notably planning documents of different levels and scope, as well as studies, programs and development models for the urbanization of this territory (Table 1). Subsequently, a comparative overview of the planning, research and institutional frameworks relevant to the left bank of the Danube was established with a focus on the period of the most extensive urban development (1945-1973) encouraged by the establishment of the PKB Agricultural Combine. Additionally, a comparative analysis was engaged to establish the relationship between the current urban development and planning of this territory and what has been conceived and planned throughout history. 
Table 1. Main sources and key contents for PKB development.

\begin{tabular}{|c|c|c|c|c|}
\hline Year & Sources & I & Key Contents (Intentions) & Period \\
\hline \multirow[t]{2}{*}{1945} & $\begin{array}{l}\text { Urbanistic study and programs for the use of the spatial } \\
\text { framework of the Danube's left riverbank for } \\
\text { agricultural purposes }\end{array}$ & $\bullet$ & creation of large social farms in the Belgrade area & \multirow{4}{*}{ 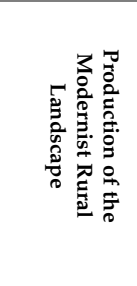 } \\
\hline & Yugoslav agrarian policy from 1945 to 1953 & ${ }^{\circ}$ & transformation of agriculture towards socialism & \\
\hline 1950 & Belgrade Master Plan (General Urban Plan) & + & $\begin{array}{l}\text { the Third Belgrade territory was not morphologically } \\
\text { and functionally defined }\end{array}$ & \\
\hline 1957 & $\begin{array}{l}\text { Decision of the National Committee of the City of } \\
\text { Belgrade for the urban definition of the Third Belgrade } \\
\text { territory for agricultural purposes }\end{array}$ & $\circ$ & $\begin{array}{l}\text { perspective of incorporating the left river belt of the } \\
\text { Danube into the urban fabric }\end{array}$ & \\
\hline \multirow{3}{*}{1958} & $\begin{array}{c}\text { Program for new settlements within the } \\
\text { Agricultural Combine }\end{array}$ & $\mathrm{x}$ & $\begin{array}{l}\text { the concept of "a city that feeds"; the typical } \\
\text { solutions of agricultural buildings }\end{array}$ & \multirow{6}{*}{ 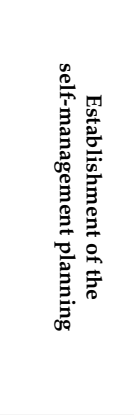 } \\
\hline & $\begin{array}{l}\text { Regulatory plan for the first region of the } \\
\text { Danube-city - Belgrade on the left bank of the Danube }\end{array}$ & + & the concept of the "lamellar city" and Danube-city & \\
\hline & $\begin{array}{l}\text { Establishment of the Planning Directorate and the } \\
\text { construction of Belgrade on the left bank of the Danube }\end{array}$ & $\mathrm{x}$ & $\begin{array}{l}\text { establishment of the Self-Management Pyramid of } \\
\text { the Combine; an autonomous planning organization, } \\
\text { independent of the Urban Institute of Belgrade }\end{array}$ & \\
\hline 1966 & General Overview of the Master Plan of 1966 & + & $\begin{array}{l}\text { determination of specific sites and urban conditions } \\
\text { for current construction }\end{array}$ & \\
\hline \multirow{2}{*}{1968} & $\begin{array}{l}\text { Regional Spatial Plan for the Danube } \\
\text { Tourism Development }\end{array}$ & + & a system of focal points for tourism and recreation & \\
\hline & $\begin{array}{l}\text { Belgrade Urbanization Plan on the left bank of } \\
\text { the Danube }\end{array}$ & + & detailed plans for seven PKB settlements & \\
\hline \multirow{3}{*}{1970} & $\begin{array}{l}\text { Study on the Development of Belgrade's economy and } \\
\text { the possibilities for its integration into the global market }\end{array}$ & $\bullet$ & $\begin{array}{l}\text { the recognition of opportunities and conditions for } \\
\text { economic integration into the global market }\end{array}$ & \multirow{6}{*}{ 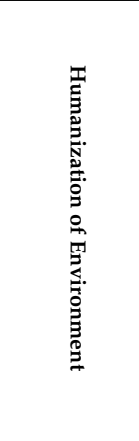 } \\
\hline & $\begin{array}{l}\text { Study "Environmental awareness and self-involvement } \\
\text { of working people and citizens in protecting and } \\
\text { improving the natural environment on the territory } \\
\text { of Belgrade" }\end{array}$ & $\bullet$ & $\begin{array}{l}\text { protection of the environment-humanization of } \\
\text { production vs. humanization of environment }\end{array}$ & \\
\hline & $\begin{array}{l}\text { Establishment of the City Board of } \\
\text { Environmental Protection }\end{array}$ & $\mathrm{x}$ & $\begin{array}{l}\text { the promotion of an urban planning approach based } \\
\text { on the "protective urbanism" concept }\end{array}$ & \\
\hline \multirow{2}{*}{1972} & Belgrade Landscape Plan & + & $\begin{array}{l}\text { rediscovery of the quality and form of the } \\
\text { natural landscape; }\end{array}$ & \\
\hline & Belgrade Master Plan & + & $\begin{array}{l}\text { the concept of "an archipelago of settlements in a sea } \\
\text { of greenery" }\end{array}$ & \\
\hline 1973 & General Housing Plans for PKB settlements & + & $\begin{array}{l}\text { the system of agro-industrial settlements in the form } \\
\text { of "independent cells of local communities" }\end{array}$ & \\
\hline 1984 & Amendments to the Belgrade Master Plan until 2002 & + & the concept of connecting the city to the Danube river & \multirow{6}{*}{ 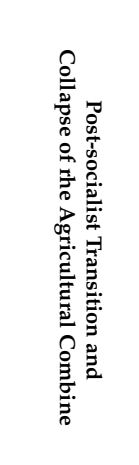 } \\
\hline 1995 & $\begin{array}{c}\text { Pan-European Biological and Landscape Diversity } \\
\text { Strategy PEBLDS }\end{array}$ & $\mathrm{x}$ & $\begin{array}{l}\text { formation of the Pan-European Ecological Network } \\
\text { (PEEN), which is composed of neighboring national } \\
\text { ecological networks countries, in order to preserve } \\
\text { long-term ecosystems, habitats and species of } \\
\text { importance for protection at the European level }\end{array}$ & \\
\hline 2003 & Belgrade Master Plan until 2021 & + & $\begin{array}{l}\text { identification of fixed elements of greenery and } \\
\text { protective greenery systems }\end{array}$ & \\
\hline 2004 & $\begin{array}{l}\text { Regional spatial plan of the administrative area of the } \\
\text { city of Belgrade }\end{array}$ & + & $\begin{array}{c}\text { directing development axes towards the territory of } \\
\text { the left bank of the Danube and creating a new urban } \\
\text { development center }\end{array}$ & \\
\hline 2010 & $\begin{array}{c}\text { Regulation on the ecological network of the Republic } \\
\text { of Serbia }\end{array}$ & $\mathrm{x}$ & $\begin{array}{l}\text { the riverside of the Danube is defined as an ecological } \\
\text { corridor of national and international importance }\end{array}$ & \\
\hline 2011 & EU strategy for the Danube region (Danube Strategy) & $\mathrm{x}$ & $\begin{array}{l}\text { the issue of environmental protection and } \\
\text { sustainable use of natural resources }\end{array}$ & \\
\hline \multicolumn{5}{|c|}{ Index of source type (I)/Clusters of sources } \\
\hline+ & Study & Program & Policy/Strategy & $\begin{array}{l}\text { Institution } \\
\text { establishmen }\end{array}$ \\
\hline
\end{tabular}

The research was conducted in 5 phases:

- Data Collection-collection of relevant data based on primary sources related to the urban planning and development of the territory of Third Belgrade. The primary sources include available historical and archival material, as well as plans and strategies that have been verified and publicly available by relevant institutions;

- Data Systematization and Clustering-chronological systematization of collected data in accordance with the type of source and their classification into clusters of sources: plan, study, program, policy, institution establishment;

- Content analysis for each cluster of sources-recognition of key intentions for the planning and development of Third Belgrade, identification of planning concepts; 
- Periodization of urban development-identification of the developmental periods of Third Belgrade in accordance with the planning framework, institutional and policy framework, and conceptual framework;

- Mapping urban development—establishing a connection between the planned and the realized, monitoring morphogenesis;

The insights into the theoretical determinants of landscape studies and studies of environmental protection and humanization, as well as their reflection in Yugoslav architectural theory and the spatial planning of the territory of Belgrade, can be considered an additional source in this research. Key sources also include the periodicals Architecture Urbanism, Urbanism of Belgrade and the Yearbook of the Museum of the City of Belgrade, as well as PKB's publishing activity in the form of the Poljoindustrija (Agroindustry) newspaper, which was conceived as a kind of report on the construction and maintenance of the Combine presented through 1774 editions, beginning in 1967. The paper recognizes that local newspapers offer a solid basis for the analysis of planning frameworks and the urban development of a particular spatial framework. It has been identified that the content of the mentioned newspaper portrays social and cultural activities, everyday life, communal problems, etc., in the local community, which has significantly influenced the transformation of the rural landscape.

\section{Findings and Discussion}

Insight into and the analysis of all the clusters of sources, including the Poljoindustrija newspaper and local periodicals, enabled chronological monitoring of the PKB development and its relationships with landscape structure, identifying four relevant phases according to which the study presentation was organized. The first period concerns the production of the modernist rural landscape since the establishment of the PKB at the end of 1945 and its first developmental phase of positioning in the comprehensive economy, industry and spatial physiognomy of the City of Belgrade. The second phase deals with the relationship between socialist ideology and landscape protection, that is, the maintenance of the agricultural landscape under the conditions of self-governing socialism, in line with the provisions of the 1968 General Urbanization Plan of Belgrade on the Left Bank of the Danube. The central focus of the third phase is on the topics of improvement and protection of the environment and humanization of environment. The fourth phase concerns the post-socialist transition and the planning perspectives after the collapse of the PKB Agricultural Combine.

\subsection{First Phase: Production of the Modernist Rural Landscape}

On the ideological and political foundations of Yugoslav agrarian policy from 1945 to 1953 , which formed an integral part of a comprehensive project based on the socialist reconstruction of agriculture after WWII, a strategic approach was developed for the creation of large social farms in the Belgrade area [40]. Immediately after the end of the war, in an interview with a delegation of agricultural experts, Josip Broz Tito, President of the Socialist Federal Republic of Yugoslavia, stated that "if agriculture is not the first, it is certainly one of the first priorities in reconstruction", emphasizing the importance of agriculture in the restoration of other branches of the economy and in line with urban development [41]. In an agrarian country such as Yugoslavia, the new government set rapid economic development as its task, and industrialization was the imperative of economic growth. It was particularly significant that industrialization led to a decrease in the agricultural population, but at the same time was a factor in the advancement of agricultural production, which required the transformation of agriculture towards socialism.

The main strategy of the City in the development of agriculture was to create agro-industrial combines that would enable a mass supply of major food products to the city. According to Radenkovic and Solar [42], the combines were conceptualized as integral systems that sought to realize a production program, guided by the slogan "from the field to the dining table" and encompassing broader activities aimed at enhancing the social standard of workers-the provision of a housing system, facilities for "extended everydayness", daily tourism options, etc. The initial stage of contemporary 
urbanization of the territory of Third Belgrade included the development of studies and programs for its use for agricultural purposes under the leadership of Arch. Branislav Kojic. The first phase of the establishment of organized agricultural production and thus the urbanization of this territory was marked by the formation of an agricultural ground in Pancevo Rit, formerly the Land Agricultural Property, on 27 December 1945 [43].

Within the Belgrade Master Plan of 1950, this territory was not morphologically and functionally defined, but it was designated as a green urban belt with predominantly agricultural activity and a residential and economic zone of a smaller spatial extent. However, the development of agricultural industrial production on the left bank of the Danube raised some more complex questions regarding this territory, causing amendments to the Master Plan based on the 1956 elaboration of approaches to urban planning and the 1957 decision of the National Committee of the City of Belgrade. This decision opened the perspective of incorporating the river belt of the left side of the Danube into the urban fabric. The first part of the study is related to the typical solutions of agricultural buildings on the basis of which the program for new settlements within the Combine was drawn up. This program was devised by the Construction Institute of the Federal Ministry of Construction, while more intensive and coordinated research work and definition of the planning framework began in 1958 with the establishment of the Planning Directorate and the construction of Belgrade on the Danube's left bank. In later years, this planning directorate was responsible exclusively for the urban development and planning of the total system of the agricultural combine. In this sense, the specificity of the institutional framework of planning is also recognized-the combine had an autonomous planning organization, independent of the Urban Institute of Belgrade.

After 16 years from the adoption of the 1950 Master Plan, the City Assembly made a decision to revise it as the result of elaboration through regulatory and detailed urban plans in order to determine specific sites and urban conditions for current construction. In the General Overview of the Master Plan of 1966, the spatial scope of the left bank of the Danube was functionally defined for the first time in the planning framework, in line with the amendments made in 1957. The comprehensive territory for agricultural exploitation under the autonomous management of PKB was divided into 6 exploitation units and 4 branches, so that each unit constituted an independent labor administration or production unit and had its own special economic program. Furthermore, each unit had its residential settlement, which consisted of an economic courtyard and a residential zone, while Padinska Skela was conceived as the central settlement of all the working people of the Combine. By determining the purpose and character of the spatial patterns of the left bank of the Danube, this territory became urban-controlled on the one hand, while on the other hand, it created a significant basis for further development of the city in the form of extensive study and design work in order to avoid mass unplanned urbanization.

In parallel with the conceptualization of the PKB spatial-planning framework, the development of Danube-city was started, guided in all its initial positive results by the realization of New Belgrade as a modernist city. The basic vision of the urbanization of the spatial coverage of the left bank of the Danube was based on the concept of a "city that feeds"-implying it should produce a food reserve for the life of Belgrade as a future million-population metropolis. The original urban concept of Danube-city introduced a "lamellar city", which organizationally consisted of a series of lamellae that made up autonomous urban units such as an urban district (Figure 2). Since the construction of New Belgrade set the dynamics of realization of other planned ventures on the territory of the City of Belgrade and, accordingly, it was impossible to reliably predict in what time interval and at which pace Danube-city would be developed, each lamella was organized as an independently functional entity autonomous from the level of construction in other lamellae. In this sense, the proposed structure was urbanistically defined in line with the comprehensive policy of the city's economic development. Based on the type of economic activities and the size of the lamellae in which activities were planned, the number of workers was determined to be 70,000 , while the average normative value of 64 jobs per hectare was defined in relation to world norms for medium-sized economic capacities. In that order, the population of Danube-city was estimated at 400,000 people, which would include 168,000 workers. 


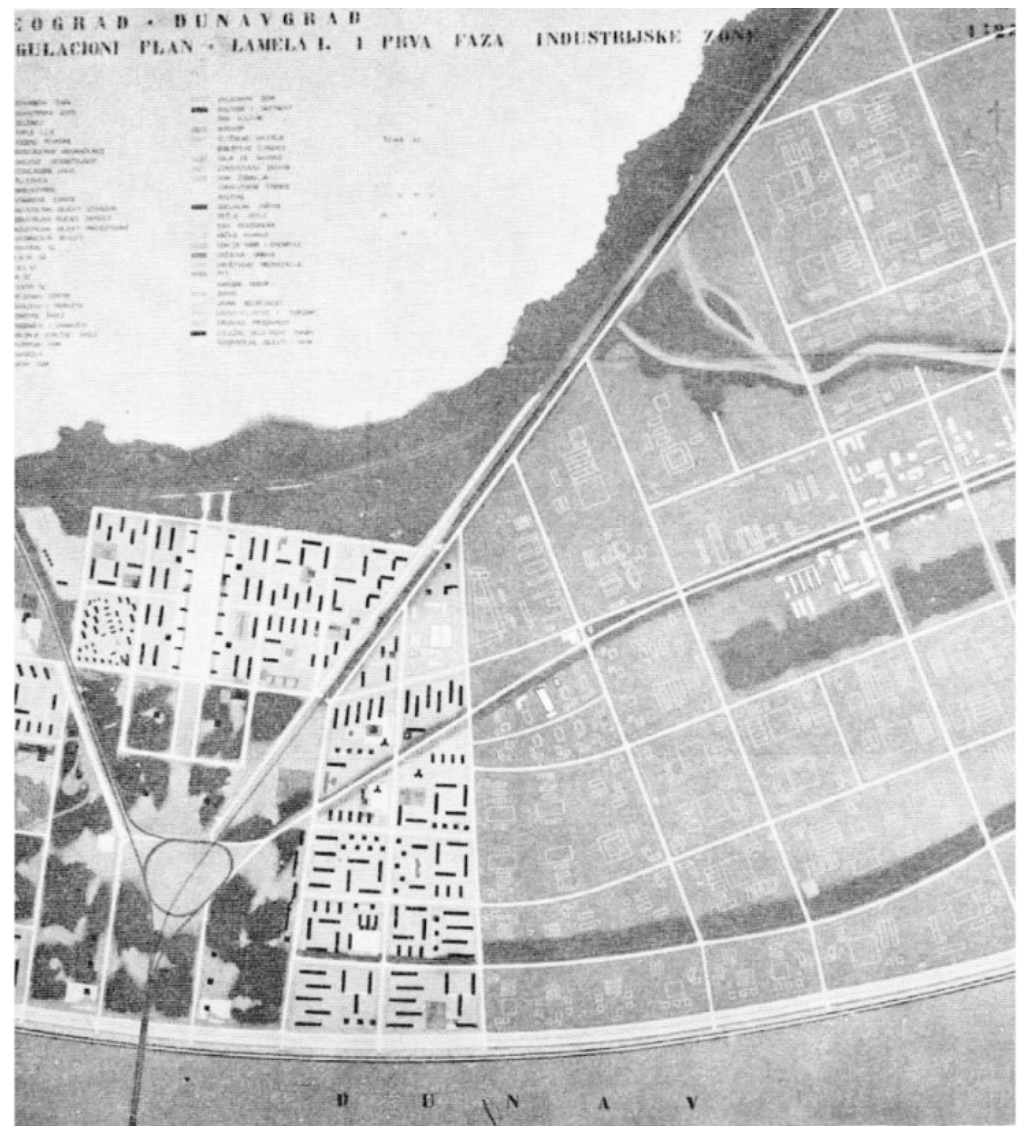

Figure 2. Regulatory plan for the first region of the Danube-city-Belgrade on the left bank of the Danube drafted by the Planning Directorate and the construction of Belgrade on the left bank of the Danube under the leadership of Arch. B. Stojanović (design team: Arch. A. Stjepanović, Arch. B. Janković with associates) in 1958. Source: [44].

\subsection{Second Phase: Establishment of the Self-Management Planning Framework}

When it comes to the landscape, most of the research focuses on the people who use and transform it. This process of transformation is an expression of the means and goals set by society, which is why the landscape is created as a consequence of the interaction between people and their environment. In this sense, several factors are relevant for observing the landscape-political, economic, cultural, ecological and social, and they depend on the approach to reading and the way of emphasizing different values of the same space. According to Zeitoun [45], the notion of landscape is a product of the understanding and use of the environment by a society. Therefore, the landscape exists only if it is transformed by society, and for that, it is necessary to determine the scale of action to be taken, who will be taking it, and the benefits that the society will derive from it. As Macura [46] (p. 42) writes, the importance of architecture and its role in the life of an individual or a community arises, on the one hand, from their reciprocity, in that "man has predetermined some important contents and forms of his life and future development," and, on the other hand, as the result of "coincidence between the characteristics of a human community at a given time and the characteristics of its architectural and urban framework."

Given that the development of the PKB system was the task of the Combine as a whole, of all its exploitation units, branches and individuals, who shared the understanding that "although they belong to a greater system, each member of the community is a small world in itself," special attention was paid to the creation of an autonomous self-management planning model. This was achieved through the continuous conduct of surveys by the PKB Self-Management Study Group, which focused primarily on the issue of improving living standards within the Combine system [47]. The "Self-Management 
Pyramid of the Combine" included over 200 self-management work units. Several of these work units made up the organizational unit, in the form of a manufacturing facility.

The structure of the "Self-Management Pyramid of the Combine" directly indicates a complementary connection between spatial and sociological levels-from the comprehensive system of the Combine to the single housing unit, from the united self-management community of workers to the working man, the self-manager. According to the sociological approach to planning, Djurovic [48] proposes to identify spatial levels in accordance with the "level of sociability"-from the personal characteristics of the individual to the comprehensive territory of the city. In order to identify relevant levels within the landscape, Delcourt and Delcourt [49] offers an organizational paradigm through which a series of spatial and temporal configurations are established, within which each level is constrained by a higher one and at the same time includes all patterns and processes that take place at a higher level of the hierarchy. Accordingly, the landscape can be considered as a system consisting of a series of hierarchical entities.

The starting point in the organization of self-management was reflected in the principle of maximum development of independent operation at all levels of the Combine, from the unit to the Combine as a whole. In that order, the entire organism of the Combine was constituted to act in the direction of the rapid independence of all its parts, including both working and organizational units and certain activities that made up the "Self-Management Pyramid." The Combine's organization functioned as a complex mechanism within which the individual was often described by the phrase "a man in the giant," while "the working people represented the greatest capital" [50] (p. 11). This implied that there was a harmony of organization and self-management so that the people were not alienated from their fundamental rights.

The influence of the working people and the Organization of Associated Work was the main lever in the development of plans. On the other hand, owing to the way of designing and adopting different types of plans-related to production, space or economy-PKB was adapted to the mechanism of the agro-industrial complex, which was seen not only in the planning procedure but also in the final content of the plans and their synchronization. In this sense, the Self-Management planning methodology made it possible for "the plans of work organizations not only to be a mechanical sum of plans but an expression of common needs, opportunities and goals" [51] (p. 7).

Within the Combine, the housing issue was one of the key factors in further development, as reflected in the living conditions of the workers and, on the other hand, the continuous arrival of the required number of experts. In order to overcome the mentioned problems, the implementation of a housing construction project was programmatically determined by the Board of Directors of the Combine based on the solidarity of all workers. Workers' living conditions were an integral part of the Combine's policy. There was a clear concept not only of the development of science and production, but also of taking care of the working man.

The basic policy of further development of the PKB thus implied self-management integration on a larger scale in order for the united working people to take over most of the state function and for such self-management to become fully integrated into the socio-economic system, suggesting integration of economy with other activities, and spatial planning. Emphasizing that the backbone of the development of the entire system of the Combine was the rise of the living standard of the working people, Aleksandar Pavlovic [47] (p. 4), Deputy General Director of the PKB, pointed out at an Annual Assembly that "standard is not just a roof over your head but an ideological struggle for socialist everyday life." At the heart of the PKB's policy was the search for a solution to the collective use of leisure time in the cultural, sports and other facilities of "extended everyday life." The basic premise was based on the active use of free time, which would contribute to work productivity and the constitution of individual and collective socialist everyday life. 


\subsection{Third Phase: Humanization of Environment}

The focus on environmental issues and the self-managing engagement of working people and citizens in protecting and improving the environment began to emerge in the late 1960s, primarily through the critical view that the development of environmental activity and awareness was not yet in line with the needs of modern society, nor in accordance with the possibilities afforded by the socialist self-government. According to the records of the Union of Engineers and Technicians of Yugoslavia, annexed by Stojanovic [52] to the report of the Committee for Conclusions and Recommendations of the Scientific Conference "Man and Environment" held in Belgrade in 1973, more than 18 significant meetings were organized between 1968 and 1975 with the topics of improvement and protection of the environment and humanization of environment, which had an impact on the development of a new humanistic appreciation of the people and their surroundings [53,54], instead of valuation based on technological results and economic growth.

The report from the mentioned scientific conference stated that "human history, human activity and human thinking arise, on the one hand, from the working, productive relationship between people and nature, and on the other, from the relation between people." In this scientific debate, Stojanovic, at the time a leading urban planner and one of the designers of the PKB urban system, recognized the impact of scientific and technological revolution and the development of means of production on man, pointing out that "by defining his work, he continues to master and humanize nature in terms of his purposeful creative activity" [55] (pp. 3-5). Popovic [56] takes a similar perspective, arguing that the self-governing socialist society will be able to bridge the contradictions between man and the environment "provided that human needs and human goals are aligned with current development" and permeate production relations with humanization in harmony with the needs of producers and citizens. As Tomic [57] (p. 25) states, one of the prerequisites for humanizing life in the city is precisely reflected in the "rediscovery of the quality and form of the natural landscape."

In order to strike a balance between humans and the environment, Stojanovic emphasizes the need to establish a "new orientation, new social relations and a new scale of values," which would at the same time enable the humanization of production and its adaptation to the needs of working people [55]. According to Friedman [58], the interaction of human cultural activities and the physical environment shapes the way in which a particular landscape is used, while its transformation qualifies in relation to the demands of society. This view was in line with the thesis on the affirmative acceptance of the shaping of the human environment, which in the context of the Combine was primarily aimed at the agricultural landscape. According to Halpern, important insights into the process of transformation of rural areas can be gained precisely by considering the "relationship to agriculture as a way of life" [24]. This relationship was the main determinant of the socialist everyday life of the working people of the Combine, as the generator of production and transformation on the left bank of the Danube.

The described perspectives had a significant influence on the further evolution of the PKB's spatial system, in the form of humanizing nature and the approach to human needs, intensifying the relationship between social development and daily life, creating new social relations and a socialist community in which nature was both a productive and an environmental category. In this period, PKB's development was in full swing. In the context of intense changes in the social and economic life of the Yugoslav state and Belgrade as its capital, PKB was considered a leading driver of growth mainly because of its highly sophisticated production system and its success record. Such developmental tendencies also contributed to the frequent use of the phrase: "PKB-Yugoslavia in a nutshell." In the traditional ranking of Economic Policy—the largest work organization in Yugoslavia, PKB always ranked high on the list of 200 most successful companies-11th in 1970, 12th in 1972, 13th in 1973 - as a leading agro-industrial organization in the sector of agriculture, which sufficiently affirms the role of agricultural industrial production as the city's major industry. On the basis of such development perspectives, the intensive Study on the Development of Belgrade's economy and the possibilities for its integration into the global market was completed in 1970, which highlights the 
extraordinary geographical predispositions of the left bank of the Danube in the context of opportunities and conditions for economic integration not only into the Yugoslav but also the global market (Figure 3).

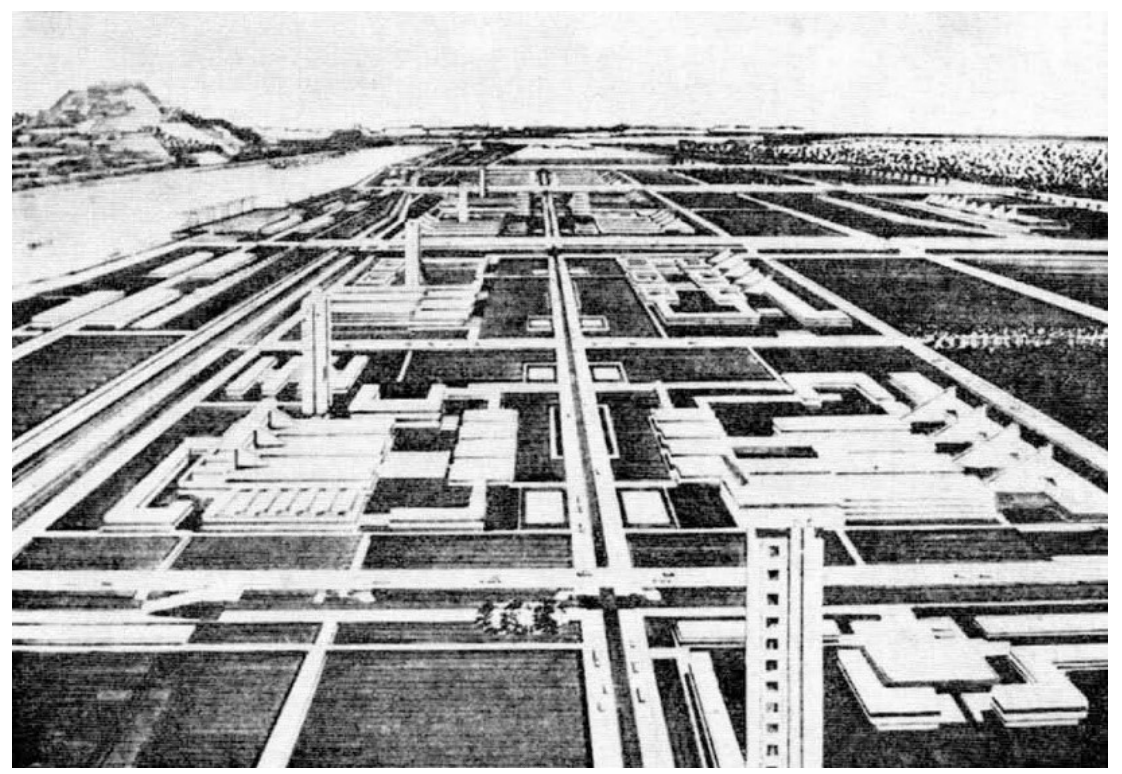

Figure 3. Informative perspective of the industrial zone on the left bank of the Danube from the study "Development of the Belgrade economy and the possibilities of its inclusion in the world market" drafted by Belgrade Chamber of Commerce, Secretariat for Economy and Faculty of Economics in Belgrade in 1970. Source: [44].

The beginning of 1972 was a turning point in the development of PKB. Guided by (1) the dynamics of the construction of a comprehensive administrative area of the city of Belgrade, within which all efforts were invested in the construction of New Belgrade as the new socialist capital, and (2) determinants of the new Master Plan, whose orientation to further progress was based on the concept of "an archipelago of settlements in a sea of greenery" that would enable "the expression of the achieved high level of harmony between the cityscape and the landscape" [59] (p. 12), the realization of previous plans for Danube-city as an economic and industrial center that was supposed to make up the largest share of the PKB housing stock was abandoned. This decision was significantly influenced by the development of the Landscape Plan, which for the first time in Belgrade's urban practice was made as an addition to the Master Plan. According to Perisic [60], the basic idea behind this plan was to treat the whole area as a "unique natural or human environment" in order to achieve a complete "life frame of man and society".

In that order, the backbone of the further growth of the PKB system was the Spatial Plan of the Belgrade Territory on the Left Bank of the Danube with a series of General Housing Plans for PKB settlements adopted in 1973. This plan was mainly based on a system of agro-industrial settlements in the form of "independent cells of local communities" built on the principles of "protective urbanism", while the housing settlement Kotezi was the only local community realized in the area of the planned Danube-city (Figure 4).

The successful economic development and positioning of the Combine also led to a more serious elaboration of the respective territory and its planning regulation, which is why in 1968 the Belgrade Urbanization Plan on the left bank of the Danube was drafted (Figure 5), which had not been included in the 1950 Master Plan of Belgrade. This plan was primarily concerned with the territory of the seven PKB settlements: Dunavac, Pionir, Partizanski prelaz, Padinska skela, Kovilovo, Lepušnica and Mladost. 

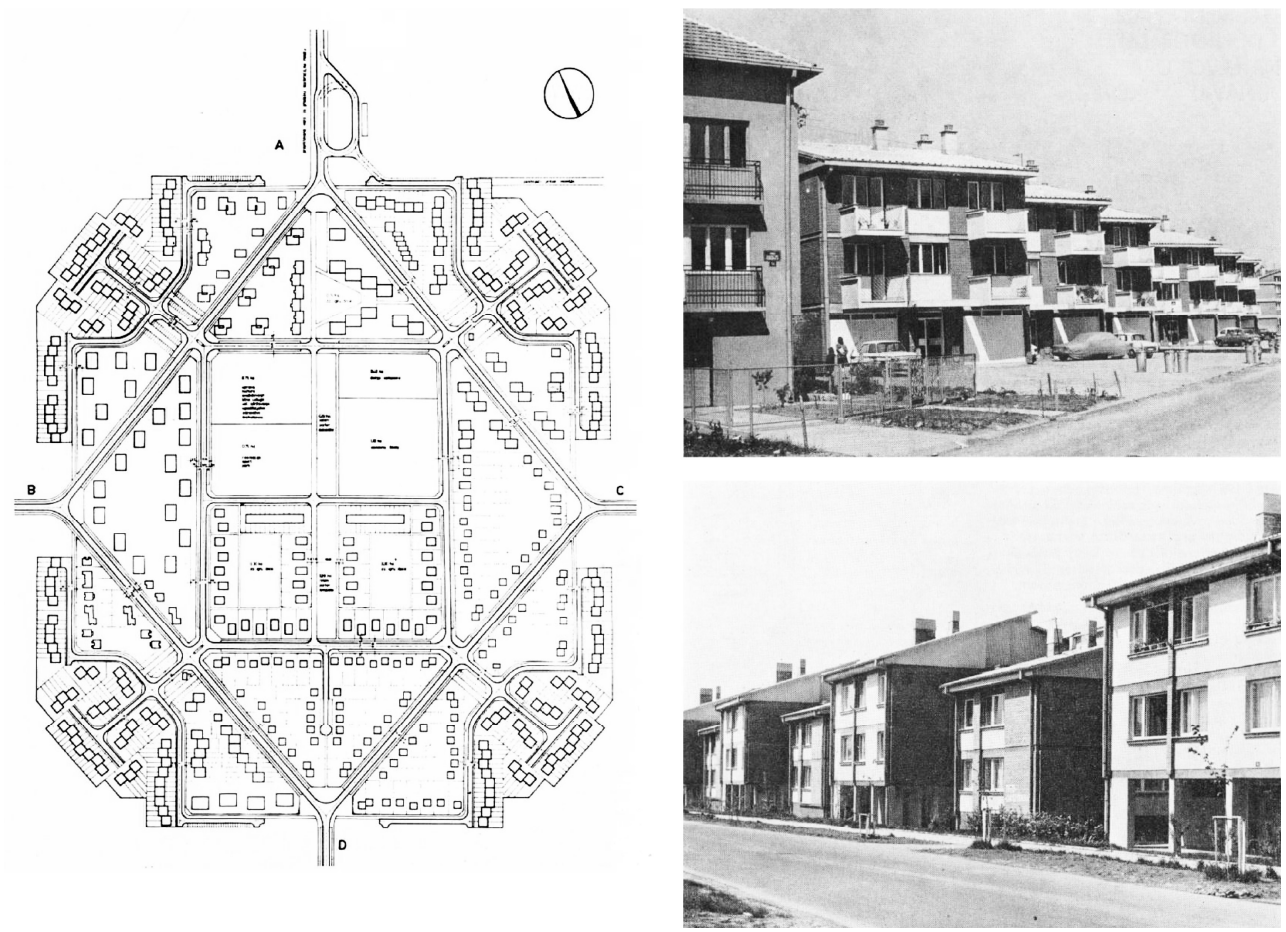

Figure 4. Detailed urban plan of the settlement Koteži, Arch. D. Barlovac (left), realization of Kotež in 1975 (right). Source: [61].

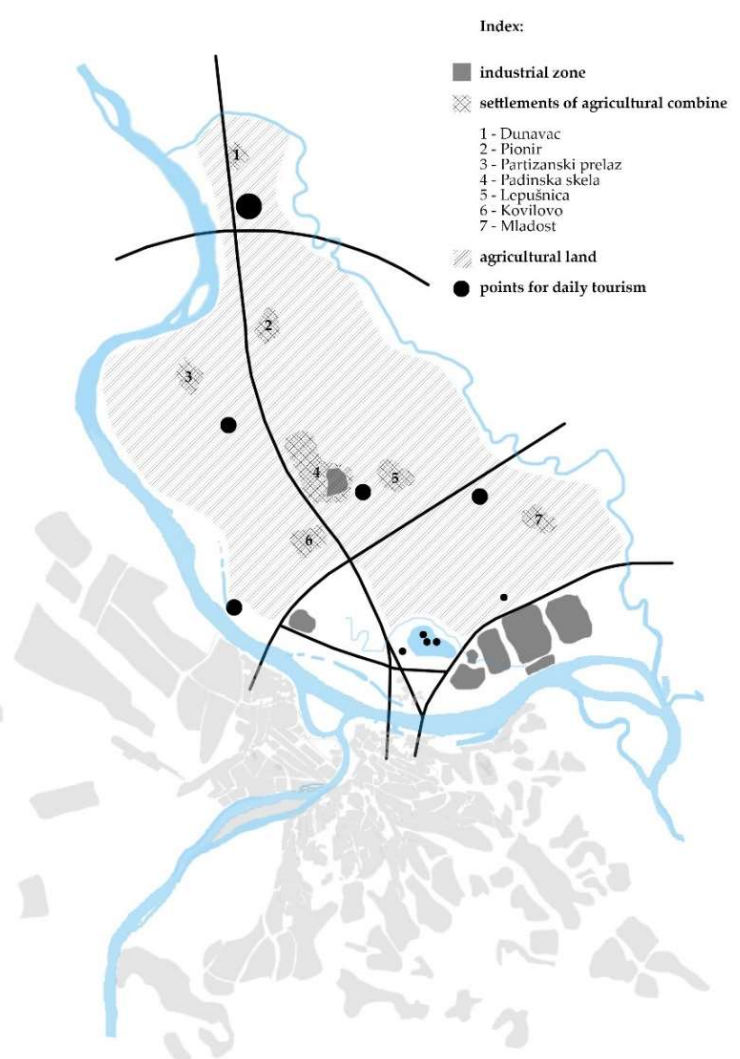

Figure 5. Urbanization plan of Belgrade on the Left Bank of the Danube-General urban solution from 1968. Source: Authors drawing based on [62].

In this period, the final preparations were completed and the new Master Plan Belgrade of 1972 was adopted, which brought a completely new attitude towards the treatment of nature and the 
environment. That same year, Yugoslav experts took part in the United Nations Conference on the Human Environment in Stockholm, which expressed the understanding that the environment is in line with comprehensive life activities and everydayness, meaning that it is not only about the biological environment but also about the quality of human existence [63]. Equally ecologically, socio-politically and economically colored, the idea of the importance of the link between socio-economic, spatial-urban planning and the prediction of environmental protection was rounded off. As Mendelson writes, in a socialist society where the leading motive for living and creating was general progress, the protection of nature and the environment, as well as the use of natural resources, should form an inseparable whole [64].

Regarding the natural conditions that characterize the spatial framework of the left riverbank of the Danube, the entire economic zone is imbued with greenery, which has multiple roles, such as to isolate residential units, protect against possible fires, create suitable conditions for rest and active recreation of workers during breaks, but also to create a specific picture of harmony between modern industrial buildings and nature. To meet these demands, detailed urban development has overlooked the systematic green distribution in the form of a grid. The key element of this system of greenery was a 200-300 m wide insulation-protection belt between residential and industrial zones, while the secondary elements were represented by local protection zones located on the outskirts of each industrial complex and along $50 \mathrm{~m}$ wide roads. As Stojanovic writes, urbanization is realistically and materially expressed "as a harmonious and balanced relationship between nature and the organized material-spatial interventions in it" and society must provide the necessary ecological balance that is a prerequisite for life.

Another significant conception in the Belgrade Urbanization Plan for the left bank of the Danube was the preservation of the coastal belt along the river in the form of a foreland, a protective zone covered in forest and intended for excursions and the everyday enjoyment of socialist nature in the most authentic Danubian/Pannonian environment. In recognition of the site's natural amenities and based on the view that "tourism, in a certain way, is one of the final forms of consumption, which begins with agricultural production", a system of focal points for tourism and recreation was planned along with PKB. This was an excellent opportunity for Belgrade to implement its program for the population's recreation and to establish itself as a major tourist center and also fit the Regional Spatial Plan for Tourism Development on the Danube adopted in 1968 (Figure 6). In this way, the entire left bank of the Danube was planned with a focus on tourist-recreational programs based on specific geographical and natural features, with the Danube as the core.

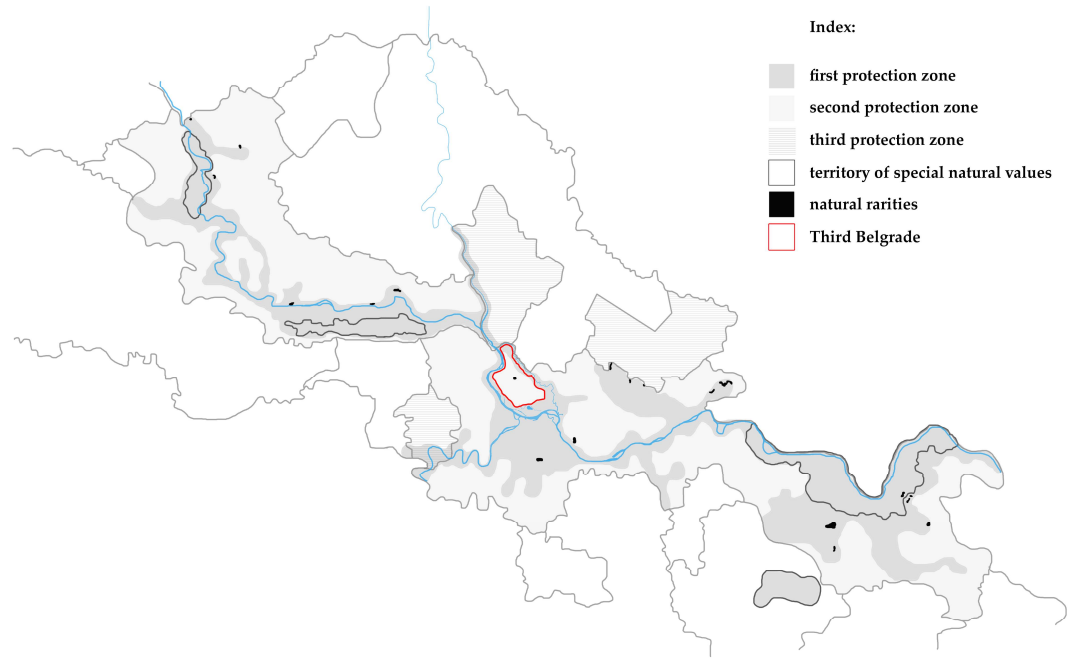

Figure 6. Regional Spatial Plan for Tourism Development on the Danube-Projected condition of green areas, 1968-Insight into the position of the PKB territory in the wider tourist-ecological system. Source: Authors drawing based on [65]. 
The PKB residential areas were designed as basic production and settlement units connected into one production and urban unit-joined-up services, plants and other PKB facilities on the one hand, and a corresponding infrastructure network on the other. Since these settlements belonged to a large economic organization, their nature and location subsequently determined their character. The concept of housing planning in the PKB system implied the construction of multiple settlements seen as "independent cells of local communities", so that the employees of the Combine could live and work near the center of production. Thus, each settlement consisted of an economic part and a residential part, with the concept also focused on the surface of the land being cultivated to minimize the distance of the roads connecting settlements to the adjacent tract [62]. According to urban parameters, the low density of housing was achieved by devoting a large share of the terrain to vacant green spaces and the necessary supporting services and facilities, while the basic urban motive proposed for solving the housing patterns was a "system of freestanding buildings set in greenery-modernly composed, with open, undeveloped ground floors" [44]. The urban complex of the settlements was designed by introducing open and semi-open urban-type public spaces and activating the free ground floors, thus enabling spatial and programmatic connections between people, buildings and nature. It can be noticed that the housing patterns were planned, designed and realized in accordance with: (1) the provisions of the Athens Charter guided by the pioneering thought of Le Corbusier, which sublimated theoretical ideas about a garden city and an industrial city dating from the first half of the 20th century with the basic premise of planning all the harmful effects of industry and traffic, also emphasizing an intense connection with nature and greenery, and (2) the Soviet pattern of the micro-district based on the symbiosis of a utopian housing commune and a garden city and following the basic principle of division into housing units set in greenery (Figure 7).
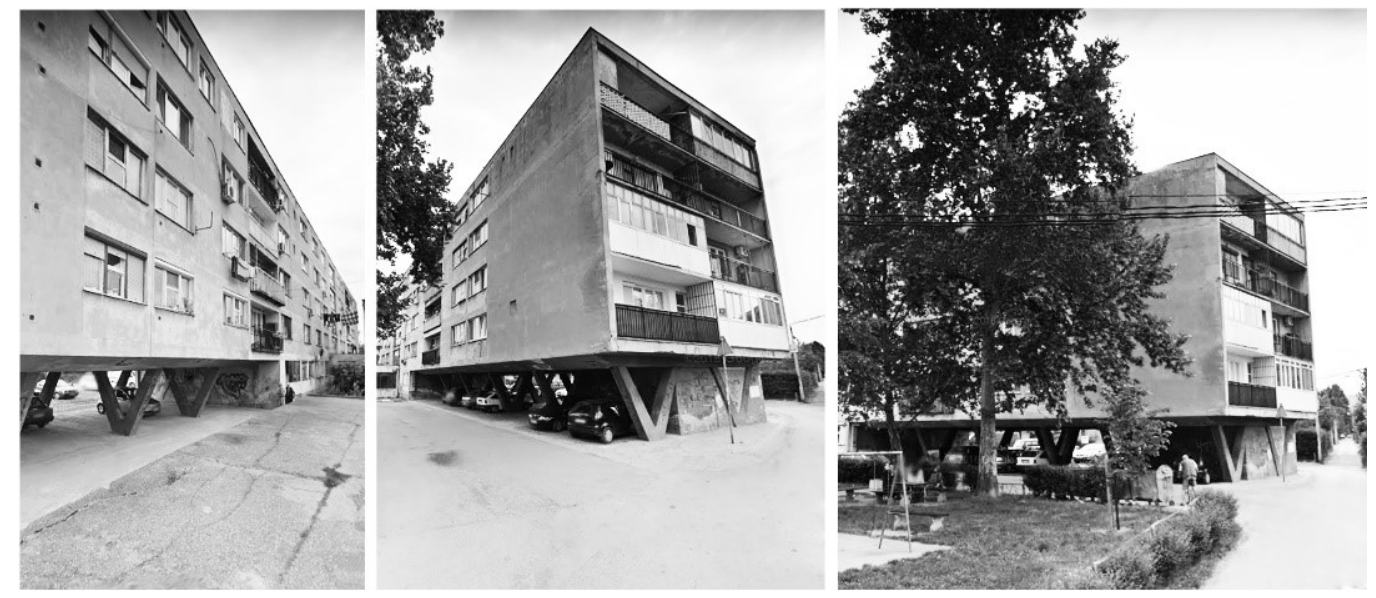

Figure 7. Photographs of a lamella realized in the residential area. Source: Authors.

\subsection{Fourth Phase: Post-Socialist Transition and the Collapse of the Agricultural Combine}

The planning framework for the territory of the Danube's left bank in the administrative area of the City of Belgrade until 1973 established a solid foundation for the planned urbanization. All plans made in the socialist period, from 1958 to 1973, were based on the development tendencies of the PKB Agricultural Combine and were directed to the agrarian policy guided by the self-management system. By the end of the 1970s, all seven planned settlements of the Combine were realized, including both the residential and the economic parts. A comparative analysis of the built area and population density by settlements, in the socialist and post-socialist period, unambiguously confirms that the development of the territory of Third Belgrade arose from the policy and planning framework of the PKB Agricultural Combine. Table 2 shows a comparative overview of the urban parameters by settlement in the PKB Agricultural Combine in the socialist and post-socialist period. Today, the total area of all seven settlements of the PKB Agricultural Combine is 796.5 ha, which is only $14.74 \%$ more 
than during their construction in socialism. It has been recognized that the increase in the area of the settlement has been achieved predominantly in the residential part, which consists of private individual houses. Furthermore, a decrease in the number of inhabitants in the settlements in the post-socialist period has contributed to a decrease in the number of inhabitants per ha in this area by an average of 12 inhabitants per ha.

Table 2. Comparative overview of urban parameters for settlements of the PKB Agricultural Combine in the socialist and post-socialist period.

\begin{tabular}{cccccccccccc}
\hline Settlement & $\begin{array}{c}\text { Gross Area of } \\
\text { Settlement (ha) }\end{array}$ & $\begin{array}{c}\text { Gross Area of } \\
\text { Residential Part of } \\
\text { Settlement (ha) }\end{array}$ & $\begin{array}{c}\text { Gross Area of } \\
\text { Economic Part of } \\
\text { Settlement (ha) }\end{array}$ & $\begin{array}{c}\text { Number of } \\
\text { Inhabitants } \\
\text { (inhabitants/ha) }\end{array}$ \\
\hline $\begin{array}{c}\text { 1-Socialist period } \\
\text { 2-Post-socialist period }\end{array}$ & 1 & 2 & 1 & 2 & 1 & 2 & 1 & 2 & 2 \\
Density \\
Dunavac & 46.80 & 63.90 & 16.25 & 33.35 & 30.55 & 30.55 & 500 & 496 & 31 & 15 \\
\hline Pionir & 63.10 & 66.20 & 22.40 & 23.10 & 40.70 & 43.10 & 1000 & 856 & 45 & 37 \\
\hline Partizanski prelaz & 62.00 & 65.10 & 22.40 & 25.40 & 39.60 & 39.70 & 1200 & 978 & 54 & 39 \\
\hline Padinska skela & 297.80 & 386.40 & 107.80 & 176.40 & 184.00 & 210.00 & 4500 & 6301 & 42 & 36 \\
\hline Kovilovo & 57.10 & 59.20 & 26.70 & 28.60 & 30.40 & 30.60 & 1200 & 920 & 45 & 32 \\
\hline Lepušnica & 75.50 & 77.40 & 35.00 & 36.20 & 40.50 & 41.20 & 1500 & 1143 & 43 & 32 \\
\hline Mladost & 76.80 & 78.30 & 25.80 & 25.90 & 51.00 & 52.40 & 1200 & 841 & 47 & 32 \\
\hline
\end{tabular}

At the moment, according to the Master Plan of Belgrade until 2021 and the Regional Spatial Plan for the administrative area of the City of Belgrade, the development axes are notably directed towards the territory of Third Belgrade, which is envisaged as a new urban development center. However, it is important to note that the boundaries of these plans do not include the entire administrative territory of the Danube's left bank, but only the riverside zone. This means that not one of the Master Plans of the City of Belgrade from 1972 until today has determined a planning framework for the territory of Third Belgrade and the settlements of the PKB Agricultural Combine.

A significant consideration for the future development of this area concerns a series of national and international documents that recognize the exceptional values of the natural features within the territory of Third Belgrade, requiring a high degree of protection and land-use in the future. Numerous nationally and internationally acknowledged documents relating to the protection of nature and the environment have highlighted the natural specifics and values of the Danube riverbank and the importance of their preservation in the planned urbanization of these territories in the future. The exceptional values of Third Belgrade are represented by its water resources-the Danube River, Lake Veliko Blato, groundwater and water sources included in the regime of sanitary protection, as well as habitats with strictly protected natural rarities, concentrated especially within the natural oasis of Beljarica. According to the Regulation on the ecological network of the Republic of Serbia, the Danube riverside is an ecological corridor of national and international importance because it connects ecologically significant areas in the territory of the Republic of Serbia and neighboring countries. Following an initiative of the Council of Europe, the Pan-European Biological and Landscape Diversity Strategy PEBLDS was signed that set as its most important task the formation of the Pan-European Ecological Network (PEEN), composed of neighboring national ecological networks countries, for the purpose of preserving long-term ecosystems, habitats and species of importance for protection at the European level [66]. Furthermore, the Council of the European Union has formally adopted the EU Strategy for the Danube Region (Danube Strategy), which focuses on the issue of environmental protection and sustainable use of natural resources in line with socio-economic and institutional development, as well as strengthening the regional cooperation of the Danube countries [67]. However, although the mentioned strategies recognize the importance of natural resources for sustainable land use, the planning framework for the territory of Third Belgrade has not yet included these perspectives in the development determinants. 


\subsection{Synthesis: Mapping Landscape Transformation of PKB}

The research identified three developmental phases in the construction of Third Belgrade profoundly marked by the socialist context and self-management planning, and one developmental phase chiefly influenced by the circumstances of post-socialist transition. For all the identified phases, an interpretive-historical analysis of the planning framework, institutional and policy framework and conceptual framework was done. Furthermore, a comparative analysis of urban parameters in the socialist and post-socialist period was made for the settlements of the PKB Agricultural Combine. Cross-examination of these frameworks made it possible to read the textuality of the plans and understand the impact of the institutional and policy context on the development of Third Belgrade territory. Through monitoring the influence of socialist agrarian policy on the planning process and what was realized, PKB was unequivocally recognized as the main producer, urban planner and realizer on the territory of the left Danube riverbank in the Belgrade administrative area.

Figure 8 shows four maps illustrating the turning points in the establishment of the urban development of not only Third Belgrade but also the entire city territory. The results suggest that the first developmental phase concerns the establishment of PKB at the end of 1945 and its positioning in the comprehensive economy, industry and spatial physiognomy of the City of Belgrade. In this phase, the 1950 Master Plan did not urbanistically define the development of the left bank of the Danube, but within the policy framework this territory was intended for agricultural purposes. The second identified phase was significantly conditioned by the development of a specific institutional framework in the form of a self-management system in which the central role was played by the working people of the Combine. Another specificity was the autonomous and independent system of planning and construction within the territory of the PKB Agricultural Combine, in relation to the general planning system of the city and its central institution, the Urban Institute of the City of Belgrade. This independent planning system based on self-management enabled the development of the first General Plan for the territory of the left bank of the Danube in 1968. The third developmental phase was profoundly influenced by the theory of landscape protection and humanization of environment in the Yugoslav cultural space, contributing to the intensification of the relationship between the working people and their cultivated environment. In this phase, ideas from the Belgrade Urbanization Plan for the left bank of the Danube received full support and the seven PKB settlements were built, thus establishing a specific morphological system of satellite-based settlements that gravitate to a corresponding spatial framework of agricultural land. The fourth map illustrates the current situation of the urban development of Third Belgrade and indicates that the current planning framework defined within the 2012 Master Plan did not address the potential for further development or preservation of the existing urban morphology of the PKB system.

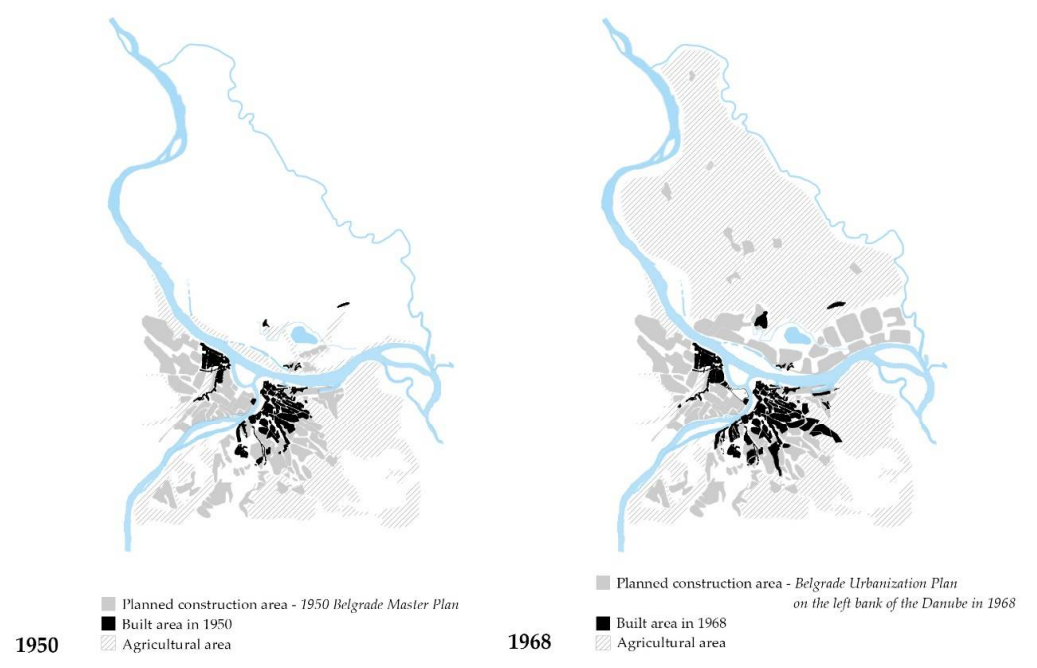

Figure 8. Cont. 

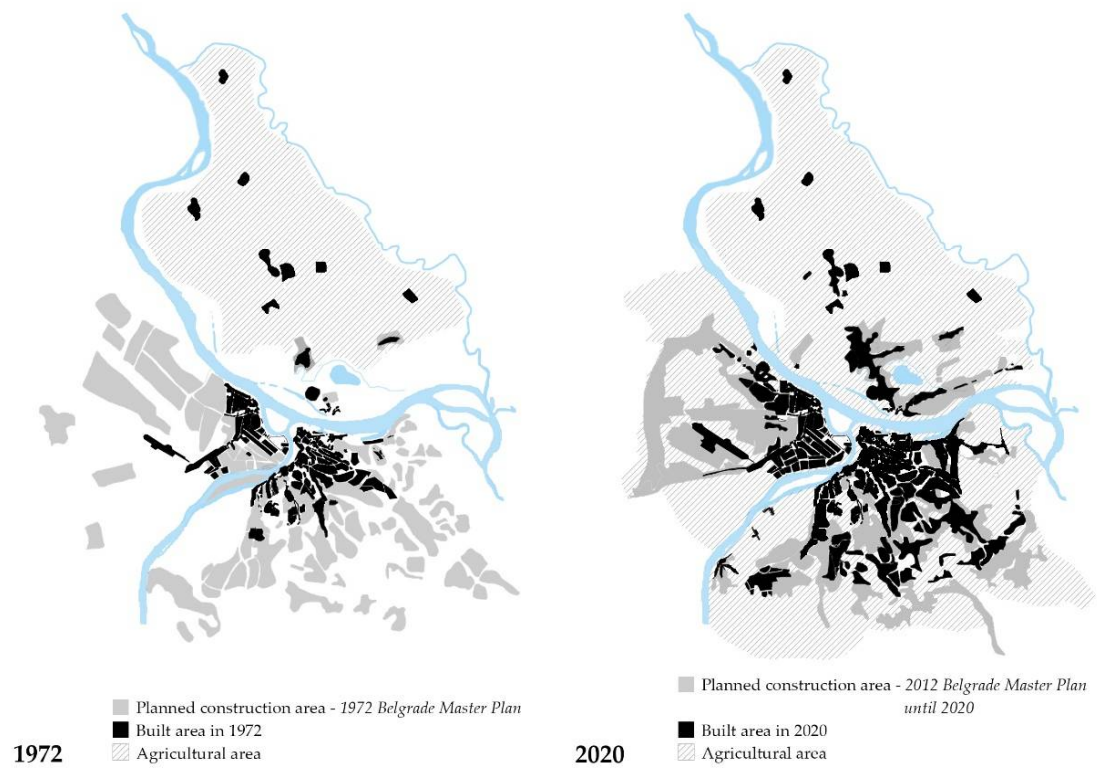

Figure 8. Morphogenesis of Third Belgrade: Cross-examination of planning framework and built area for the turning points of urban development. Source: Authors.

\section{Conclusions}

The concluding remarks were composed in accord with the initial research questions outlined at the beginning of this paper:

- What are the impacts of socialist agrarian policy on the use of land in the wider metropolitan area of Belgrade?

The research indicates that the agrarian policy, based on a strategic approach to the development of large social farms, significantly influenced the general planning of the City of Belgrade. At the cause-and-effect level, this influenced the process of modern ruralization and the immigration of a new population from rural areas to urban agglomerations. Based on the assumptions that in the future, Belgrade would turn into a million-population metropolis, the concept of "a city that feeds" was proposed to create the conditions necessary for increasing food production. Further, this indicates that the transition from an individual, autarchic economy to large-scale social industrial production corresponded with better living standards associated with urbanization. In this sense, the planning and development of the PKB Agricultural Combine illuminate and confirm the thesis that in the socialist period, most Central and Eastern European countries experienced an intensive transformation of agricultural landscapes and landscape patterns and redistribution of their relations on the basis of collectivization and self-governing management.

- What is the impact of the agricultural combine as a spatial, social, economic, environmental and political entity on the urban development process?

The example of PKB as a "producer, urban planner and realizer" on the left bank of the Danube contributes significantly to the consideration of the issue of the appearance of landscapes- "landscapes as images." In this case, the specific agricultural function is an indicator of the physical image expressed through the dominant natural elements, i.e., the produced, cultivated nature, hiding everything that generates production and constitutes the essential social basis of landscape development, or in other words, defines the area as an "ideological representation." Economic progress and the way everyday life was conducted in relation to political and social circumstances, together with the housing patterns had a significant impact on the form and structure of the Combine's comprehensive spatial system.

- What is the relationship between the ideology of socialist self-governing society and spatial planning in the context of the Belgrade Agricultural Combine (PKB)? 
Based on the chronological presentation of PKB's developmental perspectives, an intense relationship can be recognized between the landscape structure of the Belgrade City administrative area on the Danube's left bank and the ideological settings of economic development in line with the growth of a socialist, self-governing society. The PKB system was organized hierarchically in the form of a "Self-Management Pyramid of the Combine"-from the total system of the Combine to the single housing unit, from the united self-managing community of workers to the working man, the self-manager. The self-management planning system especially affirmed the architectural programming methodologies that were aimed at all the working people of the Combine, primarily through surveys focused on the issues of improving living standards within the Combine system. As stated before, the Self-Management planning methodology made it possible for the plans of work organizations not only to be a mechanical sum of plans but an expression of common needs, opportunities and goals.

- How is the production of the modernist rural landscape manifested at different spatial levels?

The relational attitudes between people and their environment are identified at several spatial and social levels-from the comprehensive territory of the left bank of the Danube, which includes agricultural arable land with the accompanying socio-functional systems, to the "independent cells of local communities," or from the self-governing pyramid as a community of working people to "the man in the giant." At the heart of the landscape production were people, in this case, the working people, the self-managers as the creators of the environment in which they lived and worked. Programmed urban planning and design based on the self-management approach have resulted in: (a) at the level of the comprehensive PKB system, seven settlements developed in accordance with the area of arable land and the estimated number of inhabitants/workers, (b) at the level of individual PKB settlements, a clear differentiation between residential, social standard and industrial spaces, and (c) at the level of housing units, an individualized design corresponding to the needs and behaviors of users. In this sense, the landscape can also be interpreted as a lens through which the character of an individual's daily life and their overall social circumstances can be very carefully observed, i.e., the landscape is established in the form of "the infrastructure or background of our collective experience."

The landscape structure of the PKB Agricultural Combine has undergone continuous processes of transformation in which the landscape has not been a fixed, immovable value or product but a construct implied by the constant shaping of social life. This indicates not only that environmental transformation cannot be separated from social transformation but also that they are in constant interaction. Furthermore, it means that an object-oriented approach is not enough to explore and interpret the landscape, but that we should rather look at the process, i.e., the function of the landscape and the way in which it is socially produced. On the basis of this representation, the landscape is established as a system for the production and transfer of meaning. In order to further affirm the recognized meaning, and identify and recognize the modernist rural landscape as a form of heritage, it is necessary to develop new, innovative research strategies and tactics in the field of architecture and urbanism that will elucidate a range of spatial and social patterns at different spatial levels and time horizons.

Following the transition from a state-governed socialist system to post-socialist conditions, a large number of Central and Eastern European states, including the countries of the Balkan region, have in recent decades experienced the process of agricultural land abandonment. This process, which can be described as equally economic, social and urban, has conditioned primarily the transformation of collective agricultural land into individual property. On the one side, previous research conducted in the context of post-socialist countries indicates that agricultural land abandonment is more pronounced in socio-economically and agro-environmentally marginal areas [32,68-72]. On the other, a case study of the PKB Agricultural Combine shows large-scale privatization of agricultural land, which makes up as much as $40 \%$ of the total administrative area of the City of Belgrade and represents a very specific example of the transformation of an agricultural landscape in the immediate hinterland of 
urban Belgrade, Serbia's capital. Furthermore, in the current planning and strategic framework, the further development of Third Belgrade is oriented towards European trends and connecting with ecological networks in the neighboring countries, which makes this example extremely specific due to its strategic position crucial to the urban development of the capital and its connection with neighbor states. Current studies examining the drivers, consequences and assessment of sustainability implications for farmland abandonment in Europe recognize two functionally different types of the land abandonment process [68]: (1) a rural exodus type of abandonment, where decreased income opportunities in rural areas have led to migrations from rural to urban areas resulting in the abandonment of agricultural land, and (2) land abandonment that resulted from the processes of transition of Eastern European and Balkan countries after the socialist era and the collapse of communist regimes-however, it is important to note here that there are differences between these countries related to the speed of the land abandonment process, which correspond to the differences in the effectiveness and depth of implementation of agricultural reforms. Thus, countries that have joined the European Union, such as Slovakia [32,71,72], with strong support for new policies in the transition process, achieved faster recultivation of abandoned agricultural lands mainly by re-fragmenting large collective farmlands into individual ones. In the case of Serbia, which is not yet a member of the European Union, due to inadequately implemented reforms of agricultural policies, the process of transforming large agricultural combines has resulted in their privatization, making further development of such territories extremely complex. In order to achieve a sustainable transformation of such territories, it is necessary to (1) harmonize planning perspectives, planning procedures and management of agricultural lands with agricultural and economic policies, and (2) to conduct in-depth qualitative and quantitative studies of the existing built area, its valorization and heritage identification in accordance with all the specifics of the typology of the modernist rural landscape that is highlighted in this study.

Author Contributions: Conceptualization: V.D., A.M.; Methodology: V.D., A.M. and J.R.T.; Writing-original draft preparation, A.M.; Writing—review and editing, V.D., J.R.T.; Visualization, A.M. All authors have read and agreed to the published version of the manuscript.

Funding: This research was funded by Ministry of Education and Science of the Republic of Serbia, grant number 451-03-68/2020-14/200090.

Conflicts of Interest: Authors declare no conflict of interest.

\section{References}

1. Hoskins, W.G. Making of the English Landscape; Penguin: London, UK, 1954.

2. Wylie, J. Landscape; Routledge: London, UK, 2007.

3. Widgren, M. Can Landscapes be Read? In European Rural Landscapes: Persistence and Change in a Globalising Environment; Palang, H., Sooväli, H., Antrop, M., Setten, G., Eds.; Springer: Dordrecht, The Netherlands, 2004; pp. 455-465. [CrossRef]

4. Macura, M. Tuge i ushiti pejzaža. Arhit. Urban. 1969, 56-57, 45.

5. Toth, R.E. Theory and language in landscape analysis, planning, and evaluation. Landsc. Ecol. 1988, 1, 193-201. [CrossRef]

6. Council of Europe. European Landscape Convention; European Treaty Series; Council of Europe: Strasbourg, France, 2005.

7. Duncan, J.S. City as Text.: Politics of Landscape Interpretation in the Kandyan Kingdom; Cambridge University Press: Cambridge, UK, 1990.

8. Daniels, S. Marxism, culture, and the duplicity of landscape. In New Models in Geography; Peet, R., Thrift, N., Eds.; Unwin-Hyman: London, UK, 1989; Volume 2, pp. 196-220.

9. Cosgrove, D. Landscape: Ecology and semiosis. In Landscape Interfaces: Cultural Heritage in Changing Landscapes; Palang, H., Fry, G., Eds.; Kluwer Academic Publishers: Dordrecht, The Netherlands, 2003; pp. 15-21.

10. Duncan, J.; Duncan, N. (Re)Reading the Landscape. Environ. Plan. D Soc. Space 1988, 6, 117-126. [CrossRef]

11. Mitchell, W.J.T. Landscape and Power; University of Chicago Press: Chicago, IL, USA, 2002. 
12. Harvey, D. Consciousness and the Urban. Experience; Basil Blackwell: Oxford, UK, 1985.

13. Lindholm, G. Land and Landscape; Linking Use, Experience and Property Development in Urban Areas. Land 2019, 8, 137. [CrossRef]

14. Lawrence, G. Globalisation, agricultural production systems and rural restructuring. In Sustainability and Change in Rural Australia; Cocklin, C., Dibden, J., Eds.; New South Wales University Press: Sydney, Australia, 2005; pp. 104-120.

15. Fisher, A.; Bell, S.; Capresi, V.; Maia, M.H.; Pallini, C. Introduction. SHS Web Conf. 2019, 63. [CrossRef]

16. Doevendans, K.; Lörzing, H.; Schram, A. From modernist landscapes to New Nature: Planning of rural utopias in the Netherlands. Landsc. Res. 2007, 32, 333-354. [CrossRef]

17. Heyde, S. The Dutch tradition of modernist landscape architecture and the legacy of Hans Warnau (1922-1995). Stud. Hist. Gard. Des. Landsc. 2018, 38, 57-72. [CrossRef]

18. Marcolin, P.; Flores, J.; Matias, I. Building the Modernist rural landscape in the Salazar's Regime: The agricultural colony of Boalhosa. SHS Web Conf. 2019, 63. [CrossRef]

19. Mandić, S. Struktura Regiona Beograda. Beograd: Generalni Urbanistički Plan 1950; Izvršni odbor N.O. Beograda: Beograd, Serbia, 1951.

20. Božović, G. Budućnost pseudourbanog predela. Arhit. Urban. 1987, 98, 4.

21. Lefebvre, H. Urbana Revolucija; Nolit: Beograd, Serbia, 1974.

22. Stefanović, D. Specifičnosti Procesa Urbanizacije u Jugoslaviji u Periodu od 1945. do 1961. Godine; Faculty of Economics-University of Belgrade: Beograd, Serbia, 1971.

23. Papić, D. Uticaj doseljenika iz ruralnih područja na gradsku sredinu. Urban. Beogr. 1973, 20, $22-23$.

24. Halpern, J.M. Farming as a Way of Life: Yugoslav Peasant Attitudes. In Soviet and East European Agriculture; Karcz, J.F., Ed.; University of California Press: Berkeley, CA, USA, 1967; pp. 356-381.

25. Fisher, A.; Bell, S.; Capresi, V.; Maia, M.H.; Pallini, C. Modernist Reinventions of the Rural Landscape; Routledge: London, UK, 2020.

26. Bereskin, E. Modern rural landscapes in contemporary heritage imaginaries: The case of Germany's southern Oderbruch. SHS Web Conf. 2019, 63, 11002. [CrossRef]

27. Renes, H.; Centeri, C.; Kruse, A.; Kučera, Z. The Future of Traditional Landscapes: Discussions and Visions. Land 2019, 8, 98. [CrossRef]

28. Duncan, J.; Ley, D. Place/Culture/Representation; Routledge: London, UK, 1993.

29. Barnes, T.J.; Duncan, J.S. Writing Worlds: Discourse, Text. and Metaphor in the Representation of Landscape; Routledge: London, UK, 1992.

30. Nikezić, A.; Marković, D. Place-Based Education in the Architectural Design Studio: Agrarian Landscape as a Resource for Sustainable Urban Lifestyle. Sustainability 2015, 7, 9711-9733. [CrossRef]

31. Milovanović, A. Treći Beograd: Pregled razvoja urbanističke misli i delovanja u periodu od 1921. godine do danas. Arhit. Urban. 2018, 16-25. [CrossRef]

32. Pazúr, R.; Lieskovský, J.; Bürgi, M.; Müller, D.; Lieskovský, T.; Zhang, Z.; Prischchepov, A.V. Abandonment and Recultivation of Agricultural Lands in Slovakia-Patterns and Determinants from the Past to the Future. Land 2020, 9, 316. [CrossRef]

33. Estel, S.; Kuemmerle, T.; Alcántara, C.; Levers, C.; Prishchepov, A.; Hostert, P. Mapping farmland abandonment and recultivation across Europe using MODIS NDVI time series. Remote Sens. Environ. 2015, 163, 312-325. [CrossRef]

34. Baumann, M.; Kuemmerle, T.; Elbakidze, M.; Ozdogan, M.; Radeloff, V.C.; Keuler, N.S.; Prishchepov, A.V.; Kruhlov, I.; Hostert, P. Patterns and drivers of post-socialist farmland abandonment in Western Ukraine. Land Use Policy 2011, 28, 552-562. [CrossRef]

35. Janus, J.; Bozek, P. Land abandonment in Poland after the collapse of socialism: Over a quarter of a century of increasing tree cover on agricultural land. Ecol. Eng. 2019, 138, 106-117. [CrossRef]

36. Milojević, M.P.; Maruna, M.; Djordjević, A. Transition of Collective Land in Modernistic Residential Settings in New Belgrade, Serbia. Land 2019, 8, 174. [CrossRef]

37. Djokić, V.; Ristić Trajković, J.; Krstić, V. An Environmental Critique: Impact of Socialist Ideology on the Ecological and Cultural Sensitivity of Belgrade's Large-Scale Residential Settlements. Sustainability 2016, 8, 914. [CrossRef]

38. Marić, I.; Niković, A.; Manić, B. Transformation of the New Belgrade urban tissue: Filling the space instead of interpolation. Spatium 2010, 22, 47-56. [CrossRef] 
39. Milinković, M.; Ćorović, D.; Vuksanović-Macura, Z. Historical Enquiry as a Critical Method in Urban Riverscape Revisions: The Case of Belgrade's Confluence. Sustainability 2019, 11, 1177. [CrossRef]

40. Miljković, D. Dosadašnji razvoj-Problemi i osnovne koncepcije budućeg razvoja Beograda. In Godišnjak Muzeja Grada Beograda; Muzej grada Beograda: Beograd, Serbia, 1964; pp. 27-72.

41. Milošević, S. Agrarna Politika u Jugoslaviji (1945-1953); Faculty of Philosophy-University of Belgrade: Beograd, Serbia, 2015.

42. Radenković, I.; Solar, M. From Arable Land through Socialist Industrialisation to the Dinner Table and Social Life. In We Have Built Cities for You: On the contradictions of Yugoslav socialism; Knežević, V., Miletić, M., Eds.; Center CZKD—Center for Cultural Decontamination: Belgrade, Serbia, 2018; pp. 155-169.

43. Kojić, B. Poljoprivredna Arhitektura. Projektovanje Privrednih i Industrijskih Zgrada, 3rd ed.; Narodna Knjiga: Beograd, Serbia, 1957.

44. Stojanović, B. Beograd na levoj obali Dunava. In Godišnjak Muzeja Grada Beograda; Muzej grada Beograda: Beograd, Serbia, 1971; pp. 333-383.

45. Zeitoun, J. Predeo. Arhit. Urban. 1969, 56-57, 27.

46. Macura, M. Međuzavisnosti reintegracije arhitektonskog prostora i samoupravnog socijalističkog razvoja. Arhit. Urban. 1978, 80-81, 49.

47. Pavlovic, A. Standard nije samo krov nad glavom-Iz izlaganja Aleksandra Pavlovića, zamenika generalnog direktora Kombinata, na godišnjoj skupštini Sindikata. In Poljoindustrija—List Radnog Kolektiva Poljoprivrednog Kombinata Beograd; PK Beograd: Beograd, Serbia, 1969; p. 4.

48. Djurovic, D. Sociološki pristup planiranju budućeg razvoja Beograda. Urban. Beogr. 1969, 4, 19.

49. Delcourt, H.R.; Delcourt, P.A. Quaternary landscape ecology: Relevant scales in space and time. Landsc. Ecol. 1988, 2, 23-44. [CrossRef]

50. Anonim. Čovek u gigantu. In Poljoindustrija-List Radnog Kolektiva Poljoprivrednog Kombinata Beograd; PK Beograd: Beograd, Serbia, 1969; p. 11.

51. Anonim. Model samoupravnog planiranja. In Poljoindustrija-List Radnog Kolektiva Poljoprivrednog Kombinata Beograd; PK Beograd: Beograd, Serbia, 1974; p. 7.

52. Stojanović, B. Zaštita čovekove okoline urbanizmom. Urban. Beogr. 1975, 31, 1-7.

53. Ristić-Trajković, J.; Stojiljković, D. Sustainability and Socialism: Socio-ecological ideas in urbanization of New Belgrade. Facta Univ. Ser. Archit. Civil Eng. 2016, 14, 343-353. [CrossRef]

54. Stojiljković, D.; Ristić, J. Development of environmental consciousness in urbanization process of Belgrade in the second half of the XX century. In Proceedings of the III International Symposium for Students of Doctoral Studies in the Fields of Civil Engineering, Architecture and Environmental Protection, Novi Sad, Serbia, 21-23 September 2011; pp. 333-338.

55. Stojanović, B. Čovek i životna sredina. Urban. Beogr. 1973, 23, 3-5.

56. Popović, S. Ostvarivanje zaštite životne sredine u jugoslovenskom samoupravnom sistemu. In Zbornik Radova Pravnog Fakulteta iz Niša; Univerzitet u Nišu - Pravni fakultet, Niš: Serbia, 1979; pp. 5-47.

57. Tomić, V. Humanizacija života u gradu. Urban. Beogr. 1980, 59-60, 25-27.

58. Friedman, A.D. The Legal Choice in a Cultural Landscape: An Explanatory Model Created from the Maritime and Terrestrial Archaeological Record of the Roanoke River, North Carolina; PAST Foundation: Columbus, OH, USA, 2008.

59. Djordjevic, A. Ekspoze. Urban. Beogr. 1972, 19, 11-19.

60. Perišić, D. Tretiranje prirodne sredine u fazi generalnog urbanističkog planiranja. Urban. Beogr. 1972, 19, 63-65.

61. Stojanović, B. For an analytical review of the current housing construction: Koteži (In Serbian). Urban. Beogr. 1975, 30, 61-62.

62. Strugar, M. Prostorni plan Beograda na levoj obali Dunava i Generalni planovi naselja PKB-a. Urban. Beogr. 1980, 56, 59-60.

63. United Nations. Report of the United Nations Conference on the Human Environment, Stockholm, 5-16 June 1972; United Nations: New York, NY, USA, 1973.

64. Mendelson, A. Razmišljanja o čovekovoj okolini i stanovanju. In Godišnjak Muzeja Grada Beograda; Muzej grada Beograda: Beograd, Serbia, 1976; pp. 259-277.

65. Stojanović, B. Greenery in Spatial Planning. Arhit. Urban. 1969, 56-57, 54-55. (In Serbian) 
66. European Commission. Pan-European Biological and Landscape Diversity Strategy, Nature and Environment. In Proceedings of the Council of Europe at the Ministerial Conference "Environment for Europe", Sofia, Bulgaria, 23-25 October 1995; Council of Europe Press: Strasbourg, France, 1996.

67. European Commission. The EU Strategy for the Danube Region-A United Response to Common Challenges; European Union, Directorate-General for Regional Policy: Brussels, Belgium, 2011.

68. Ustaoglu, E.; Collier, M.J. Farmland abandonment in Europe: An overview of drivers, consequences, and assessment of the sustainability implications. Environ. Rev. 2018, 26, 396-416. [CrossRef]

69. Alix-Garcia, J.; Kuemmerle, T.; Radeloff, V.C. Prices, land tenure institutions, and geography: A matching analysis of farmland abandonment in post-socialist Eastern Europe. Land Econ. 2012, 88, 425-443. [CrossRef]

70. Prishchepov, A.V.; Müller, D.; Dubinin, M.; Baumann, M.; Radeloff, V.C. Determinants of agricultural land abandonment in post-Soviet European Russia. Land Use Policy 2013, 30, 873-884. [CrossRef]

71. Pazúr, R.; Lieskovský, J.; Feranec, J.; Ot’ahel', J. Spatial determinants of abandonment of large-scale arable lands and managed grasslands in Slovakia during the periods of post-socialist transition and European Union accession. Appl. Geogr. 2014, 54, 118-128. [CrossRef]

72. Bezák, P.; Mitchley, J. Drivers of change in mountain farming in Slovakia: From socialist collectivisation to the Common Agricultural Policy. Reg. Environ. Chang. 2014, 14, 1343-1356. [CrossRef]

Publisher's Note: MDPI stays neutral with regard to jurisdictional claims in published maps and institutional affiliations.

(C) 2020 by the authors. Licensee MDPI, Basel, Switzerland. This article is an open access article distributed under the terms and conditions of the Creative Commons Attribution (CC BY) license (http://creativecommons.org/licenses/by/4.0/). 